\title{
MODEL LATIHAN KOORDINASI DALAM BENTUK VIDEO MENGGUNAKAN VARIASI TEKANAN BOLA UNTUK ATLET TENIS LAPANGAN TINGKAT YUNIOR
}

\author{
Irfan Arifianto ${ }^{1)}$, Septian Raibowo ${ }^{2)}$. \\ ${ }^{1}$ Fakultas Ilmu Keolahragaan, Pendidikan Kepelatihan Olahraga, Universitas Negeri Padang \\ email: irfan19@fik.unp.ac.id \\ ${ }^{2}$ Fakultas Keguruan \& Ilmu Pendidikan, Pendidikan Jasmani, Universitas Bengkulu \\ email: septianraibowo@unib.ac.id
}

\begin{tabular}{l}
\hline Artikel Info \\
\hline Koresponden penulis : \\
Irfan Arifianto \\
Email: irfan19@,fik.unp.ac.id \\
$\square$ Diterima 22 September 2020 \\
$\square$ Direview 31 Oktober 2020 \\
$\square$ Disetujui 31 Oktober 2020 \\
$\square$ Dipublikasi 31 Oktober 2020
\end{tabular}

Kata Kunci:

Model Latihan, Variasi Tekan Bola, Tenia Lapangan

Keywords:

Exercise Model, Variation of Press Ball, Tennis Court

\begin{abstract}
Abstrak
Dalam mencetak atlet yang berprestasi dalam bidang tenis lapangan di perlukan penguasaan dan pengenalan teknik dasar terlebih dahulu. Salah satu komponen fundamental yang harus dikuasai terlebih dahulu yaitu koordinasi. Koordinasi merupakan salah satu dari bagian komponen-kompenen biomotor kondisi fisik. Komponen biomotor kondisi fisik yang baik berguna sebagai penyokong atau pendukung dari tingkat ketrampilan yang dimiliki oleh individu tersebut. Penelitian ini bertujuan untuk mengembangkan model latihan koordinasi menggunakan variasi tekanan bola dikemas dalam format video. Dalam pengembangan model latihan koordinasi menggunanakan variasi tekanan bola pada tenis lapangan ini, peneliti mengacu pada pengembangan Research \& Development (R\&D). Hasil Penelitian yang didapatkan pada uji coba kelompok besar adalah 91,5\% (sangat valid).
\end{abstract}

\footnotetext{
Abstract [Times New Roman 11CetakTebal dan Miring]

In order to producing excellent tennis athletes, we have to require to things, mastery and basic technique introduction. A fundamental components that must be mastered first is coordination. Coordination is a part of physical condition biometer components. A good biometer physical components are useful in invididual level skills. This study aims to develop coordination exercise model using the ball pressure variation that's packaged by a video. In this development, reseacher referred the Research \& Development $(R \& D)$. The result of this study obtained in large group trial were 91,5\% (very valid).
} 


\section{PENDAHULUAN}

Kebugaran jasmani sangat penting bagi masyarakat untuk dapat melakukan aktifitas sehari-hari tanpa merasakan kelelahan yang sangat berarti. Aktifitas yang dilakukan sangat beragam, mulai dari bertani, berkebun, berdagang, menjadi pegawai kantoran. Semua aktifitas yang dilakukan dapat berjalan secara maksimal jika tubuh terasa bugar dan sehat. Menjaga kesehatan tubuh dapat dilakukan dengan cara menjaga pola makan, berolahraga secara rutin dan melakukan pola hidup sehat.

Dalam menjaga dan membuat tubuh menjadi sehat dan bugar, aktifitas yang bisa dilakukan adalah dengan berolahraga. Olahraga ada serangkaian gerakan yang dilakukan untuk menjaga dan memelihara kebugaran jasmani, rohani dan sosial. Kegiatan berolahraga dapat dilakukan mulai dari anak-anak hingga orang dewasa. Disamping menjaga kebugaran tubh, olahraga juga dapat dijadikan sebagai saran untuk mencapai prestasi di bidang cabang olahraga tertentu. Macam-macam olahraga yaitu beladiri, atletik dan permainan. Beberapa olahraga yang termasuk kedalam permainan, yaitu sepakbola, bolavoli, bola basket, tenis lapangan dan olahraga permainan lainnya.

Tenis lapangan merupakan salah satu dari beberapa olahraga yang sangat popular di dunia dan banyak digemari oleh semua lapisan masyarakat, dan juga suatu permainan yang menyenangkan dan menggairahkan (Raibowo, 2018,). Tidak ada batasan umur baik bagi pria maupun wanita untuk dapat melakukan dan menikmati permainan tenis lapangan.

Permainan tenis lapangan adalah suatu permainan yang dimainkan di atas lapangan berbentuk persegi panjang dan di pisah menjadi 2 (dua) bagian oleh net serta menggunakan alat bantu berupa raket dan bola (Raibowo, 2018).

Pada saat sekarang ini, perkembangan olahraga ini berkembang sangat pesat dan diminati oleh banyak kalangan. Hal ini dapat dibuktikan dengan menjamurnya klub-klub tenis yang terbentuk. Klub-klub tersebut awalnya hanya sebagai wadah penyaluran hobi bagi masyarakat yang menyenangi tenis lapangan, tetapi sedikit bergeser kepada arah prestasi. Salah satu tempat pelatihan yang ada di seluruh Indonesia adalah klub binaan PELTI yang ada di daerah.

Dalam mencetak atlet yang berprestasi dalam bidang tenis lapangan di perlukan penguasaan dan pengenalan teknik dasar terlebih dahulu, yaitu teknik groundstroke (forehand \& backhand), serve \& volley (Salim, 2008:47). Sebelum memulai pengenalan dan berlatih teknik dasar, terdapat salah satu komponen fundamental yang harus dikuasai terlebih dahulu yaitu koordinasi.

Koordinasi merupakan salah satu dari bagian komponen-kompenen biomotor kondisi fisik. Komponen biomotor kondisi fisik yang baik berguna sebagai penyokong 
atau pendukung dari tingkat ketrampilan yang dimiliki oleh individu tersebut.

Komponen biomotor kondisi fisik yang harus dimiliki oleh atlet tenis lapangan adalah (a) kekuatan, (b) daya tahan, (c) kecepatan, (d)koordinasi (e) fleksibilitas. Koordinasi dalam tenis lapangan berdasarkan klasifikasinya yaitu kelincahan, keseimbangan, koordinasi (mata, tangan, kaki), diferensiasi, orientasi, ritme dan reaksi (Yonda, 2020)

Dari komponen-komponen biomotor kondisi fisik tersebut, komponen kondisi fisk koordinasi merupakan salah satu komponen kondisi fisik yang dibutuhkan dalam tenis lapangan. Hal ini dikarenakan koordinasi menjadi biomotor pendukung komponen kondisi fisik lainnya serta mempermudah belajar teknik dan taktik. Koordinasi merupakan kemampuan untuk melakukan gerakan dengan berbagai tingkat kesulitan secara tepat dan cepat serta efisien (Irianto, 2002). Tanpa memiliki koordinasi yang baik maka akan mempersulit kesesuaian dan keselarasan irama gerak pada saat melakukan latihan.

Latihan mempunyai banyak pendekatan dan model untuk diterapkan, tergantung jenis cabang olahraga dan tujuan yang ingin dicapai dari proses latihan tersebut. Diperlukan suatu proses latihan, waktu yang cukup dan didukung oleh banyak faktor (Budiwanto, 2012). Latihan merupakan suatu proses yang dilakukan secara sistematis dan berulang-ulang serta memiliki prinsip beban berlebih yang bertujuan untuk meningkatkan ketrampilan teknik, taktik, mental dan strategi.

Dalam proses latihan, meningkatkan ketrampilan atlet dapat dilakukan dengan menerapkan beberapa metode latihan yang berbeda, sebagai upaya untuk memberikan variasi latihan dan mengindari kejenuhan atlet. Akibat dari latihan yang cenderung monoton dapat menimbulkan kebosanan saat berlatih. Pemberian variasi latihan dapat mengurangi tingkat kejenuhan dan kebosanan atlet dalam berlatih dan dapat meningkatkan semangat atlet dalam berlatih dikarenakan dengan adanya variasi-variasi latihan yang baru (Saputro, 2017).

Model latihan tenis lapangan yang sesuai dengan perkembangan anak adalah berbasis permainan. To help provide a strong and united position on how tennis is introduced to starter players, I believe it is important for all of our member nations to show their support of the massages within Tennis Play and Stay (ITF, 2012). Maksud dari play \& stay itu sendiri adalah bagaimana pemain pemula itu bermain dan menyenangkan sehingga pemain tetap akan berlatih tenis tanpa rasa bosan. Untuk berlatih tenis lapangan dengan mudah maka diperlukan bola tenis lapangan yang lunak dengan klasifikasi red ball, orange ball \& green ball.

Bola lunak merupakan bola tenis yang mempunyai tekanan yang sedikit lebih lembut 
dari bola tenis standar lainnya, yang berfungsi untuk berlatih bagi petenis pemula. Gerakan latihan menggunakan bola lunak dapat dilakukan dalam berbagai gerakan seperti, melempar, mengayun maupun melontar dan memberikan beban tambahan pada gerakan (Lumintuarso, 2013)

\section{KAJIAN LITERATUR}

\section{a. Koordinasi}

Komponen biomotor koordinasi diperlukan hampir di semua cabang olahraga pertandingan maupun perlombaan, sebab unsur-unsur dasar teknik gerak dalam cabang olahraga melibatkan sinkronisasi dalam beberapa kemampuan. Dimana dalam beberapa kemampuan tersebut menjadi serangkaian gerak yang selaras, serasi dan simultan sehingga gerak yang dilakukan nampak luwes dan mudah. Dengan demikian sasaran utama pada latihan koordinasi adalah untuk meningkatkan kemampuan penguasaan gerak.

Penguasaan kecakapan fisik koordinasi dalam bidang olahraga merupakan salah satu point yang sangat penting untuk dapat mencapai keahlian atau penguasaan keterampilan. Oleh karena itu tanpa memiliki kemampuan koordinasi yang baik, maka atlet akan kesulitan dalam melakukan teknik secara selaras, serasi dan simultan, sehingga nampak luwes dan mudah. Keuntungan bagi atlet yang memiliki kemampuan koordinasi baik, akan mampu menampilkan keterampilan dengan sempurna dan dapat segera mengatasi permasalahan tugas (gerak) yang muncul tidak terduga selama latihan.

Kemampuan koordinasi seorang atlet dipengaruhi oleh pembawaan atlet itu sendiri dan unsur kondisi fisik seperti kelincahan, kelentukan dan keseimbangan. Hal penting yang berpengaruh terhadap kemampuan koordinasi adalah latihan. Faktor-faktor yang mempengaruhi kemampuan koordinasi tersebut dapat diciptakan dan diupayakan melalui latihan secara sistematis, teratur dan kontinyu. Dengan latihan yang dilakukan secara berulang-ulang gerakan yang memerlukan koordinasi akan dapat dilakukan dengan mudah bahkan dapat menjadi gerakan yang otomatis (Sajoto, 1988).

Koordinasi erat kaitannya dengan keterlibatan bagian tubuh, yaitu koordinasi mata-kaki dalam menendang bila atau berjalan, koordinasi mata-tangan dalam gerakan motorik halus dan gerakan motorik kasar. Gallahue (1996) Various parts of the body may be involved, such as eye-foot coordination, as in kicking a ball or walking upstairs. Eye-hand coordination is evident in fine motor activities such as bead stringing, tracking, and clay modeling or in gross motor activities such as catching, striking, or volleying a ball .

Dalam tenis lapangan hal yang sangat fundamental dalam pembentukan penguasaan ketrampilan gerak salah satu nya adalah koordinasi. Hal tersebut senada dengan pendapat Rowland (2014) yang menyatakan 
"in tennis, for example agility, speed, balance, eye-hand coordination, muscle endurance, and rapid reflexes are important to expert performance on the court", dan Bryant (2004) eye-hand coordination is based on past experiences of throwing and catching an object similar in size to a tennis ball".

Suwarno (2001) anak usia 10-12 tahun masuk kepada fase pengembangan kedua dimana pada usia ini lebih banyak dilatihkan unsur-unsur teknik dasar.

Tabel 1. Fase Perkembangan

\begin{tabular}{llll}
\hline Olahraga & $\begin{array}{c}\text { Umur } \\
\text { Mulai } \\
\text { Olahraga }\end{array}$ & $\begin{array}{c}\text { Umur } \\
\text { Pengkhusus } \\
\text { an }\end{array}$ & $\begin{array}{c}\text { Golde } \\
\text { n Age }\end{array}$ \\
\hline Atletik & $10-12$ & $13-14$ & $18-23$ \\
\hline $\begin{array}{l}\text { Bola } \\
\text { Basket }\end{array}$ & $7-8$ & $10-12$ & $20-25$ \\
\hline Bola Voli & $11-12$ & $14-15$ & $20-25$ \\
\hline $\begin{array}{l}\text { Sepak } \\
\text { Bola }\end{array}$ & $10-12$ & $11-13$ & $18-24$ \\
\hline $\begin{array}{l}\text { Tenis } \\
\text { Lapangan }\end{array}$ & $6-8$ & $12-14$ & $22-25$ \\
\hline
\end{tabular}

(Sumber: Bompa, 2009)

Dalam cabang olahraga tenis lapangan usia 6-8 tahun adalah usia yang sangat tepat untuk pengenalan teknik-teknik dasar tenis lapangan dan pada usia tersebut juga merupakan tahap awal pengenalan kepada tahap pengkhususan teknik-teknik tenis lapangan salah satunya adalah latihan koordinasi. Selain itu juga pada usia tersebut, pemberian pemahaman dan penguasaan gerak akan lebih mudah terbentuk.

\section{b. Bola Tenis Lapangan}

Standar ukuran bola tenis adalah dengan diameter antara 2,5 inchi dan $25 / 8$ inchi $(6,35$ $\mathrm{cm}$ dan $6,67 \mathrm{~cm}$ ), berat bola antara 56,70 gram sampai 58,50 gram dan daya pantulnya sesuai dengan batasan dan aturan yang ditetapkan oleh ITF (Salim, 2008).

Ukuran tekanan bola menurut Statham (2007) "Balls may be pressurised or pressureless. Pressureless balls must not have greater than 1 psi $(7 \mathrm{kPa})$ ”.

Tabel 2. Ukuran Tekanan Bola

\begin{tabular}{|c|c|c|c|c|}
\hline & $\begin{array}{c}\text { Type } \\
1 \\
\text { (Fast) }\end{array}$ & $\begin{array}{c}\text { Type } 2 \\
\text { (Mediu } \\
\text { m }\end{array}$ & $\begin{array}{c}\text { Type } \\
\mathbf{3} \\
\text { (Slow) }\end{array}$ & $\begin{array}{c}\text { High } \\
\text { Altitud } \\
\text { e }\end{array}$ \\
\hline Berat & $\begin{array}{l}56.0- \\
59.4 \mathrm{~g}\end{array}$ & $\begin{array}{l}56.0- \\
59.4 \mathrm{~g}\end{array}$ & $\begin{array}{l}56.0- \\
59.4 \mathrm{~g}\end{array}$ & $\begin{array}{l}56.0- \\
59.4 \mathrm{~g}\end{array}$ \\
\hline Ukuran & $\begin{array}{c}6.54- \\
6.86 \\
\mathrm{~cm}\end{array}$ & $\begin{array}{c}6.54- \\
6.86 \mathrm{~cm}\end{array}$ & $\begin{array}{c}7.00- \\
7.30 \\
\mathrm{~cm}\end{array}$ & $\begin{array}{c}6.54- \\
6.86 \mathrm{~cm}\end{array}$ \\
\hline Pantulan & $\begin{array}{c}138- \\
151 \\
\mathrm{~cm}\end{array}$ & $\begin{array}{c}135- \\
147 \mathrm{~cm}\end{array}$ & $\begin{array}{c}135- \\
147 \\
\mathrm{~cm}\end{array}$ & $\begin{array}{c}122- \\
135 \mathrm{~cm}\end{array}$ \\
\hline $\begin{array}{c}\text { Forward } \\
\text { Deformatio } \\
n\end{array}$ & $\begin{array}{c}0.56- \\
0.74 \\
\mathrm{~cm}\end{array}$ & $\begin{array}{c}0.56- \\
0.74 \mathrm{~cm}\end{array}$ & $\begin{array}{c}0.56- \\
0.74 \\
\mathrm{~cm}\end{array}$ & $\begin{array}{c}0.56- \\
0.74 \mathrm{~cm}\end{array}$ \\
\hline $\begin{array}{c}\text { Return } \\
\text { Deformatio } \\
n\end{array}$ & $\begin{array}{c}0.74- \\
1.08 \\
\mathrm{~cm} \\
\end{array}$ & $\begin{array}{c}0.80- \\
1.08 \mathrm{~cm}\end{array}$ & $\begin{array}{c}0.80- \\
1.08 \\
\mathrm{~cm} \\
\end{array}$ & $\begin{array}{c}0.80- \\
1.08 \mathrm{~cm}\end{array}$ \\
\hline Warna & $\begin{array}{l}\text { White } \\
\text { Or } \\
\text { Yello } \\
\text { w }\end{array}$ & $\begin{array}{l}\text { White Or } \\
\text { Yellow }\end{array}$ & $\begin{array}{c}\text { White } \\
\text { Or } \\
\text { Yello } \\
\text { w }\end{array}$ & $\begin{array}{c}\text { White } \\
\text { Or } \\
\text { Yellow }\end{array}$ \\
\hline
\end{tabular}

(Sumber: ITF, 2017:19)

c. Latihan

Latihan menurut Harsono (1988:101) "adalah proses yang sistematis dari berlatih atau bekerja, yang dilakukan secara berulangulang, dengan kian hari kian menambah jumlah beban latihan atau pekerjaannya". Sistematis di sini maksudnya adalah terencana, terurut, menurut jadwal, menurut 
http://jurnal.unipasby.ac.id/index.php/stand/about/submissions jurnal.stand@unipasby.ac.id

pola dan sistem tertentu, metodis, dari mudah ke sukar, latihan yang teratur, dari yang sederhana ke yang lebih kompleks.

Sedangkan Budiwanto (2012:16) menjelaskan bahwa "latihan merupakan proses melakukan kegiatan olahraga yang dilakukan berdasarkan program latihan yang disusun secara sistematis, bertujuan untuk meningkatkan kemampuan atlet dalam upaya mencapai prestasi yang semaksimal mungkin, terutama dilaksanakan untuk persiapan untuk menghadapi suatu pertandingan".

Dari beberapa pernyataan di atas dapat disimpulkan bahwa latihan adalah suatu kegiatan yang dilakukan dengan terprogram dan dilakukan secara berulang-ulang dan tersistematis dengan mempunyai tujuan tertentu secara maksimal.

\section{METODE PENELITIAN}

Metode penelitian yang digunakan adalah metode penelitian pengembangan. Winarno (2013) penelitian pengembangan merupakan penelitian yang berupa mengembangkan produk tertentu sesuai dengan kebutuhan masyarakat saat ini.

Dalam pengembangan model latihan koordinasi menggunanakan variasi tekanan bola pada tenis lapangan ini, peneliti mengacu pada pengembangan Research \& Development (R\&D) dari Borg \& Gall (1983) yang terdiri dari 10 langkah. Akan tetapi prosedur tersebut bukan merupakan langkah baku yang harus diikuti secara lengkap, dikarenakan disesuaikan dengan situasi, kondisi khusus yang dibutuhkan. Ardhana (2002) prosedur pelaksanaan penelitian pengembangan bukan merupakan langkahlangkah yang baku yang harus diikuti secara kaku, setiap pengembang tentu saja dapat memilih dan menentukan langkah-langkah yang paling tepat bagi dirinya berdasarkan kondisi khusu yang dihadapinya dalam proses pengembangan. Sehingga dari 10 langkah pengembangan yang dikemukakan, peneliti hanya menggunakan langkah ke 1 hingga 7 saja, karena disesuaikan dengan kebutuhan penelitian.

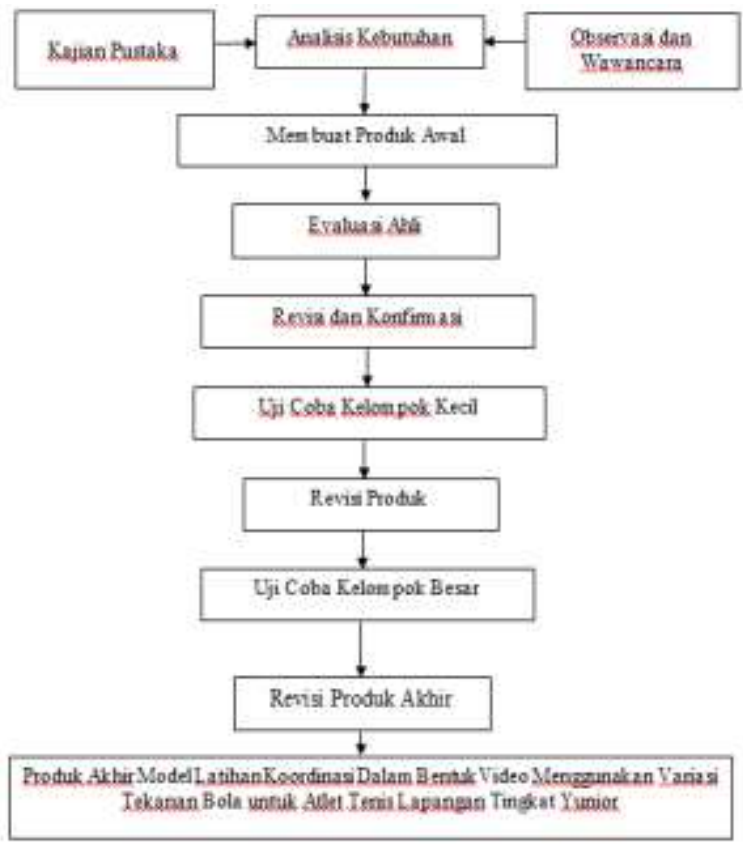

Gambar 1. Langkah-langkah Research \& Development (R\&D)

Subjek uji coba dalam penelitian ini adalah:

a. Subjek penelitian awal (analisis kebutuhan) pada 5 pelatih dan 12 atlet tenis tingkat yunior

Volume 1 Nomor 2 Tahun 2020 | 83 
b. Uji coba kelompok kecil dengan 15 atlet tenis tingkat yunior dengan menggunakan random sampling

c. Uji coba kelompok besar dengan 40 atlet tenis tingkat yunior menggunakan random sampling

Jenis data berupa kualitatif dan kuantitatif. Data kuantitatif ini diperoleh oleh dari tinjauan expert judgment, sedangkan data kuantitatif diperoleh dari analisis kebutuhan untuk mengetahui persentase kebutuhan produk yang akan dikembangkan serta dari uji coba kelompok kecil dan besar.

Instrumen pengumpulan data yang digunakan adalah instrument non tes yaitu observasi, wawancara dan angket yang berupa butir-butir soal.Teknik analisis data yang digunakan dalam penelitian dan evaluasi dari expert judgment untuk uji produk adalah teknik analisis deskriptif persentase;

a. Analisis kualitatif digunakan untuk menganalisis hasil pengumpulan data dari tinjauan expert judgment yang meliputi ahli media dan ahli materi tenis lapangan dengan menggunakan pendekatan kuantitatif. Data ini berupa saran dan masukan untuk pengembangan yang lebih lanjut

b. Analisis deskriptif yang berupa persentase digunakan untuk menganalisis hasil pengumpulan data dari penelitian awal (analisis kebutuhan), uji coba kelompok kecil dan uji coba kelompok besar.

Rumus untuk mengolah data yang berupa deskriptif persentase (Akbar \& Sriwiyana, 2010) adalah sebagai berikut:

a. Rumus untuk mengolah data persubjek uji coba

$$
\mathrm{V}=\frac{\mathrm{TSEV}}{\mathrm{S}-\max } \times 100 \%
$$

Keterangan

$\begin{array}{ll}\text { V } & \text { : Validitas } \\ \text { Tsev : Total skor empirk validator } \\ \text { S-Max : Skor maksimal yang } \\ \text { diharapkan }\end{array}$

b. Rumus untuk mengolah data secara keseluruhan subjek uji coba

$$
\mathrm{V}=\frac{\sum \mathrm{TSEV}}{\sum \mathrm{S}-\max } \mathrm{X} 100
$$

Keterangan

$\mathrm{V}$ : Validitas

$\Sigma$ Tsev : Total skor empirk validator

$\Sigma^{\text {S-Max }}:$ Skor maksimal yang diharapkan

Untuk menentuk kesimpulan yang telah dicapai, maka ditetapkan klasifikasi persentase sebagai berikut:

\begin{tabular}{|c|c|c|}
\hline Persentase & Kategori & Keterangan \\
\hline $86 \%-100 \%$ & Sangat Valid & $\begin{array}{l}\text { Dapat } \\
\text { digunakan tanpa } \\
\text { revisi }\end{array}$ \\
\hline $70 \%-85 \%$ & Cukup Valid & $\begin{array}{l}\text { Dapat } \\
\text { digunakan } \\
\text { dengan revisi } \\
\text { kecil }\end{array}$ \\
\hline $60 \%-69 \%$ & Kurang Valid & $\begin{array}{l}\text { Kurang layak } \\
\text { digunakan, } \\
\text { disarankan tidak } \\
\text { dipergunakan }\end{array}$ \\
\hline $0 \%-50 \%$ & Tidak Valid & $\begin{array}{l}\text { Tidak dapat } \\
\text { digunakan }\end{array}$ \\
\hline
\end{tabular}

Tabel 3. Klasifikasi

(Sumber, Akbar \& Sriwiyana, 2010)
4. HASIL DAN PEMBAHASAN
a. Hasil 
Data analisis kebutuhan terhadap pelatih dan atlet diperoleh data (1) $90,30 \%$ atlet menjawab metode latihan yang diberikan oleh pelatih adalah demonstrasi langsung; (2) $100 \%$ atlet menjawab materi latihan yang sering diberikan pelatih adalah berupa latihan fisik, teknik dan taktik; (3) pelatih dan atlet memerlukan model latihan koordinasi dalam bentuk video dengan menggunakan variasi tekanan bola sebagai latihan dasar.

Data evaluasi ahli materi tenis lapangan mengenai produk awal yang dikembangkan adalah sebagai berikut;

Tebel 4. Evaluasi Ahli

\begin{tabular}{|c|c|c|c|c|c|}
\hline No & Aspek & $\begin{array}{c}\text { TSE } \\
\text { V }\end{array}$ & $\begin{array}{l}\text { S- } \\
\text { M } \\
\text { ax }\end{array}$ & $\mathbf{V}$ & Kategori \\
\hline 1 & Kesesuaian & 82 & 92 & $\begin{array}{l}89,1 \\
\% \%\end{array}$ & $\begin{array}{c}\text { Sangat } \\
\text { valid }\end{array}$ \\
\hline 2 & Kemudahan & 30 & 40 & $75 \%$ & $\begin{array}{l}\text { Cukup } \\
\text { valid }\end{array}$ \\
\hline 3 & $\begin{array}{l}\text { Kemanfaata } \\
\mathrm{n}\end{array}$ & 30 & 40 & $75 \%$ & $\begin{array}{l}\text { Cukup } \\
\text { valid }\end{array}$ \\
\hline 4 & $\begin{array}{l}\text { Menyenang } \\
\text { kan }\end{array}$ & 40 & 40 & $\begin{array}{c}100 \\
\%\end{array}$ & $\begin{array}{l}\text { Sangat } \\
\text { valid }\end{array}$ \\
\hline 5 & Kecocokan & 40 & 40 & $\begin{array}{c}100 \\
\%\end{array}$ & $\begin{array}{c}\text { Sangat } \\
\text { valid }\end{array}$ \\
\hline 6 & Kelayakan & 4 & 4 & $\begin{array}{c}100 \\
\%\end{array}$ & $\begin{array}{c}\text { Sangat } \\
\text { valid }\end{array}$ \\
\hline & Jumlah & 224 & $\begin{array}{c}25 \\
6\end{array}$ & & \\
\hline & Rata-rata & & & $\begin{array}{c}\mathbf{8 9 , 8} \\
\%\end{array}$ & $\begin{array}{c}\text { Sangat } \\
\text { valid }\end{array}$ \\
\hline
\end{tabular}

Data evaluasi ahli media mengenai produk awal yang dikembangkan adalah sebagai berikut;
Tabel 5. Evaluasi Ahli Media

\begin{tabular}{|c|c|c|c|c|c|}
\hline $\begin{array}{l}\mathbf{N} \\
\mathbf{o}\end{array}$ & Aspek & $\begin{array}{l}\text { TSE } \\
\mathbf{V}\end{array}$ & $\begin{array}{c}\text { S- } \\
\text { Ma } \\
\text { xa }\end{array}$ & V & $\begin{array}{c}\text { Kategor } \\
\text { i }\end{array}$ \\
\hline 1 & $\begin{array}{l}\text { Kemenarika } \\
\mathrm{n}\end{array}$ & 19 & 20 & $95 \%$ & $\begin{array}{l}\text { Sangat } \\
\text { valid }\end{array}$ \\
\hline 2 & Ketepatan & 18 & 20 & $90 \%$ & $\begin{array}{l}\text { Sangat } \\
\text { valid }\end{array}$ \\
\hline 3 & Kejelasan & 3 & 4 & $75 \%$ & $\begin{array}{l}\text { Cukup } \\
\text { valid }\end{array}$ \\
\hline 4 & Kemudahan & 3 & 4 & $75 \%$ & $\begin{array}{l}\text { Cukup } \\
\text { valid }\end{array}$ \\
\hline 5 & $\begin{array}{l}\text { Kelengkapa } \\
\mathrm{n}\end{array}$ & 4 & 4 & $\begin{array}{c}100 \\
\%\end{array}$ & $\begin{array}{l}\text { Sangat } \\
\text { valid }\end{array}$ \\
\hline \multirow[t]{3}{*}{6} & Komposisi & 3 & 4 & $75 \%$ & $\begin{array}{l}\text { Cukup } \\
\text { valid }\end{array}$ \\
\hline & Jumlah & 50 & 56 & & \\
\hline & Rata-rata & & & $85 \%$ & $\begin{array}{c}\text { Cukup } \\
\text { valid }\end{array}$ \\
\hline
\end{tabular}

Data dari uji coba kelompok kecil dengan atlet tingkat yunior dapat dilihat sebagai berikut;

Tabel 6. Uji Coba Kelompok Kecil

\begin{tabular}{|c|c|c|c|c|c|}
\hline $\begin{array}{l}\mathbf{N} \\
\mathbf{0}\end{array}$ & Aspek & $\begin{array}{l}\text { TS } \\
\text { E } \\
\text { V }\end{array}$ & $\begin{array}{c}\text { S- } \\
\text { Ma } \\
\text { X }\end{array}$ & $\mathbf{V}$ & $\begin{array}{l}\text { Katego } \\
\text { ri }\end{array}$ \\
\hline 1 & $\begin{array}{l}\text { Kemudahan } \\
\text { pemahaman } \\
\text { penjelasan } \\
\text { langkah- } \\
\text { langkah } \\
\text { latihan }\end{array}$ & 80 & 96 & $\begin{array}{c}83,3 \\
\%\end{array}$ & $\begin{array}{l}\text { Cukup } \\
\text { valid }\end{array}$ \\
\hline 2 & $\begin{array}{l}\text { Pemahaman } \\
\text { cara } \\
\text { melakukan }\end{array}$ & $\begin{array}{c}11 \\
5\end{array}$ & 128 & $\begin{array}{c}89,8 \\
\%\end{array}$ & $\begin{array}{l}\text { Sangat } \\
\text { valid }\end{array}$ \\
\hline 3 & $\begin{array}{l}\text { Pemahaman } \\
\text { setelah } \\
\text { praktek }\end{array}$ & 91 & 96 & $\begin{array}{c}94,7 \\
\%\end{array}$ & $\begin{array}{l}\text { Sangat } \\
\text { valid }\end{array}$ \\
\hline 4 & $\begin{array}{l}\text { Kemudahan } \\
\text { dilakukan }\end{array}$ & 92 & 112 & $\begin{array}{c}82,1 \\
\%\end{array}$ & $\begin{array}{l}\text { Cukup } \\
\text { valid }\end{array}$ \\
\hline 5 & Kemenarikan & $\begin{array}{c}10 \\
4\end{array}$ & 128 & $\begin{array}{c}81,2 \\
\%\end{array}$ & $\begin{array}{l}\text { Cukup } \\
\text { valid }\end{array}$ \\
\hline \multirow[t]{3}{*}{6} & Kemanfaatan & $\begin{array}{c}10 \\
0\end{array}$ & 112 & $\begin{array}{c}89,2 \\
\%\end{array}$ & $\begin{array}{l}\text { Sangat } \\
\text { valid }\end{array}$ \\
\hline & Jumlah & $\begin{array}{c}58 \\
2 \\
\end{array}$ & 672 & & \\
\hline & Rata-rata & & & $\begin{array}{c}86,7 \\
\%\end{array}$ & $\begin{array}{c}\text { Sangat } \\
\text { valid }\end{array}$ \\
\hline & $\begin{array}{l}\text { Data dari } \\
\text { gan atlet tin } \\
\text { gai berikut; }\end{array}$ & at & a $k$ & $\begin{array}{l}\text { ompok } \\
\text { dapat }\end{array}$ & $\begin{array}{l}\text { besar } \\
\text { dilihat }\end{array}$ \\
\hline
\end{tabular}

Volume 1 Nomor 2 Tahun 2020 | 85 
Tabel 7. Uji Kelompok Besar

\begin{tabular}{|c|c|c|c|c|c|}
\hline $\begin{array}{l}\mathbf{N} \\
\mathbf{o}\end{array}$ & Aspek & $\begin{array}{c}\text { TSE } \\
\mathbf{V}\end{array}$ & $\begin{array}{c}\text { S- } \\
\mathbf{M a} \\
\mathbf{x}\end{array}$ & $\mathbf{V}$ & $\underset{\text { ri }}{\text { Katego }}$ \\
\hline 1 & $\begin{array}{l}\text { Kemudahan } \\
\text { pemahaman } \\
\text { penjelasan } \\
\text { langkah- } \\
\text { langkah } \\
\text { latihan }\end{array}$ & 196 & 216 & $\begin{array}{c}90,7 \\
\%\end{array}$ & $\begin{array}{c}\text { Sangat } \\
\text { valid }\end{array}$ \\
\hline 2 & $\begin{array}{l}\text { Pemahama } \\
\text { n cara } \\
\text { melakukan }\end{array}$ & 271 & 288 & $94 \%$ & $\begin{array}{l}\text { Sangat } \\
\text { valid }\end{array}$ \\
\hline 3 & $\begin{array}{l}\text { Pemahama } \\
\text { n setelah } \\
\text { praktek }\end{array}$ & 206 & 216 & $\begin{array}{c}95,3 \\
\%\end{array}$ & $\begin{array}{l}\text { Sangat } \\
\text { valid }\end{array}$ \\
\hline 4 & $\begin{array}{l}\text { Kemudahan } \\
\text { dilakukan }\end{array}$ & 224 & 252 & $\begin{array}{c}88,8 \\
\%\end{array}$ & $\begin{array}{c}\text { Sangat } \\
\text { valid }\end{array}$ \\
\hline 5 & $\begin{array}{l}\text { Kemenarik } \\
\text { an }\end{array}$ & 259 & 288 & $\begin{array}{c}89,9 \\
\%\end{array}$ & $\begin{array}{c}\text { Sangat } \\
\text { valid }\end{array}$ \\
\hline 6 & $\begin{array}{l}\text { Kemanfaata } \\
n\end{array}$ & 229 & 252 & $\begin{array}{c}90,8 \\
\% \\
\end{array}$ & $\begin{array}{c}\text { Sangat } \\
\text { valid }\end{array}$ \\
\hline & Jumlah & 1385 & $\begin{array}{c}151 \\
2 \\
\end{array}$ & & \\
\hline & Rata-rata & & & $\begin{array}{c}91,5 \\
\%\end{array}$ & $\begin{array}{c}\text { Sangat } \\
\text { valid }\end{array}$ \\
\hline
\end{tabular}

\section{b. Pembahasan}

Produk akhir dari penelitian ini berupa variasi latihan yang menekan pada latihan koordinasi dalam bentuk video dengan menggunakan variasi tekanan bola bagi atlet tingkat yunior tenis lapangan.

Model latihan koordinasi yang dikembangkan menggunakan variasi tekanan bola, dimana setiap model memiliki dua variasi latihan, yaitu;

a) Mini square and static cone, yang bertujuan melatih koordinasi matatangan dan ketepatan menangkap bola dengan gerakan statis;

b) Mini square and dynamic cone, yang bertujuan melatiha koordinasi matatangan dan ketepatan menangkap bola dengan gerakan dinamis; c) Square and static cone, yang bertujuan melatih koordinasi matatangan dan ketepatan menangkap bola dengan di tengahnya dibatasi oleh net dengan gerakan statis;

d) Square and dynamic cone, yang bertujuan melatih koordinasi matatangan dan ketepatan menangkap bola dengan di tengahnya di batasi oleh net dengan gerakan dinamis;

e) Catch ball free hand and throw back, yang bertujuan untuk melatih koordinasi mata-tangan dan kelincahan;

f) Coach right and left ball, yang bertujuan melatih koordinasi matatangan dan kelincahan;

g) Right catch right up, bertujuan untuk melatihan koordinasi mata-tangan dan ketepatan menangkap bola;

h) Hit ball free with racket, yang bertujuan melatih koordinasi dengan menggunakan raket;

i) Hit ball to zone with racket, bertujuan untuk melatih koordinasi dengan menggunakan raket.

Untuk bermain tenis lapangan, pada dasarnya diperlukan latihan koordinasi yang terukur dan terencana. Seorang pemain tenis akan kelihatan mempunyai koordinasi gerak yang baik, apabila dia dapat bergerak kearah bola sambil mengayun raket, selanjutnya memukul dengan teknik yang benar dan luwes (Sajoto, 1988). 
Dalam proses tersebut diperlukan program latihan yang tersusun secara sistematis dan terukur, agar tujuan yang diinginkan tercapai. Budiwanto (2012) kegiatan olahraga yang dilakukan berdasarkan program latihan yang disusun secara sistematis, bertujuan untuk meningkatkan kemampuan atlet dalam upaya mencapai prestasi yang semaksimal mungkin, terutama dilaksanakan untuk persiapan untuk menghadapi suatu pertandingan.

Koordinasi merupakan aspek yang paling dasar dalam tenis lapangan, dikarenakan pada aspek tersebut tercipta pembentukan dan penguasan ketrampilan gerak. Hal tersebut senada dengan pendapat Rowland (2014:87) yang menyatakan "in tennis, for example agility, speed, balance, eye-hand coordination, muscle endurance, and rapid reflexes are important to expert performance on the court",

Pada olahraga tenis lapangan, pemberian porsi latihan koordinasi yang banyak pada tingkat yunior (6-12 tahun) adalah pilihan yang sangat tepat dikarenakan pada usia tersebut, pemberian pemahaman dan penguasaan gerak akan lebih mudah terbentuk. Anak usia 10-12 tahun masuk kepada fase pengembangan kedua dimana pada usia ini lebih banyak dilatihkan unsurunsur teknik dasar (Suwarno, 2001).

Latihan koordinasi yang dikembangkan dikemas dalam bentuk video. Perpaduan antara media yang digunakan dan strategi pembelajaran yang sesuai diyakini banyak pihak akan mampu meningkatkan dorongan pebelajar (atlet) untuk berlatih (Raibowo, 2018). Baharudin (2012) pemilihan prosedur yang sesuai dengan melibatkan multimedia akan menarik perhatian pebelajar (atlet) untuk berlajar (latihan).

Materi dalam produk yang dikembangkan dikemas dalam bentuk video ini menyajikan informasi yang terpisah-pisah hingga mendapatkan jenis pengetahuan terkecilnya, misalnya satu menu pilihan materi yang mewakili satu jenis pengetahun (fakta, konsep, prosedur dan prinsip). Hal tersebut dilakukan sebagai bentuk upaya agar informasi yang disampaikan menjadi jelas dan mudah dipahami dengan tidak membutuhkan waktu yang banyak, serta memilik tingkat kegunaan yang tinggi pula reusability (Reigeluth \& Nelson, 2000).

Kemudian, manfaat dari produk yang dikembangkan ini dapat membantu dalam proses transfer infomasi yang terjadi dalam proses latihan secara runtun dan sistematis. Chung, Sung \& Hou (2006) bahan ajar yang diprodukis dengan bantuan penggunaan teknologi (system) akan tampak lebih terpadu dan sistematis serta memberikan informasi lebih dalam dan lebih luas untuk belajar (berlatih).

\section{KESIMPULAN}

Salah satu aspek kebugaran jasmani yaitu, koordinasi merupakan aspek sangat

Volume 1 Nomor 2 Tahun 2020 | 87 
penting pada olahraga tenis lapangan, dikarenakan pada aspek tersebut merupakan fase dimana pembentukan dan penguasaan ketrampilan gerak. Penggunaan media video dan strategi adalah pilihan yang sangat tepat dikarenakan pada prinsipnya penggunaan teknologi itu memudahkan sesuatu hal untuk mudah dipahami.

\section{REFERENSI}

Akbar \& Sriwiyana. (2010). Pengembangan Kurikulum dan Pembelajaran Ilmu Pengetahuan Sosial (IPS). Yogyakarta: PT Cipta Media.

Baharuddin, R. (2012). Pengaruh Penerapan Strategi Pembelajaran Problem Based Learning (PBL) versus Expository berbantuan Multimedia Interaktifdan Gaya Belajar terhadap Hasil Belajar Fiqih dan Retensi Mahasiswa. Disertasi tidak diterbitkan. Malang: Pascasarjana UniversitasNegeri Malang.

Budiwanto, S. (2012). Metodologi Latihan Olahraga. Malang: UM Press

Bompa, O, T \& Gregory Haff. (2009). Theory and Methodology of Training. New York: United States of America.

Gallahue, D, L. (1996). Developmental Physical Education for Today's Children. Third Edition. USA: Times Mirror Company.

ITF. (2012). Tennis 10s - Official Programme of; The International Tennis Federation. Londong: Manual Book
Irianto. (2002). Dasar Kepelatihan. Diktat. Yogyakarta: FIK UNY

Lumintuarso, R. (2013). Pembinaan Multilateral bagi Atlet Pemula. Yogyakarta: UNY Press.

Raibowo, S. (2018). Pengembangan Multimedia Interaktif Tenis Lapangan untuk Mahasiswa Jurusan Pendidikan Jasmani dan Kesehatan. DISERTASI dan TESIS Program Pascasarjana UM

Rowland, T, W. 2014. Tennisology. USA: Human Kinetics.

Salim, A. (2008). Buku Pintar Tenis. Bandung: Penerbit Nuansa

Sajoto, M. (1988). Pembinaan Kondisi Fisik dalam Olahraga. Jakarta: Departemen Pendidikan dan Kebudayaan Direktorat Jendral Pendidikan Tinggi Proyek Pengembangan Lembaga Pendidikan Tenaga Kependidikan.

Saputro, D. B., \& Supriyadi, S. (2017). Pengembangan Variasi Latihan Sepak Sila Sepak Takraw Untuk Tingkat Pemula. Indonesia Performance Journal, 1(2), 112-118.

Suwarno, (2001). Sepakbola; Gerakan Dasar dan Teknik Dasar. Yogyakarta: Prodi Pendidikan Kepelatihan Olahraga FIKUniversitas Negeri Yogyakarta.

Statam, A. (2007). Subjective and Objective Assesment of Tennis Racket Performance In Play. Tesis tidak diterbitkan. United Kingdom: Loughborough University.

Winarno. M.E (2011). Metode Penelitian dalam Pendidikan Jasmani. Malang: Media Cakrawala Utama Press

Yonda, O. (2020). Konsep Latihan Kekuatan dan Kondisi Fisik untuk Atlet Tenis Usia Muda. Media Komunikasi Petenis Indonesia-Newsletter: PELTI 